\title{
A focus of feline babesiosis at Kaapschehoop on the Mpumalanga escarpment
}

Feline babesiosis is an enigmatic disease. The causative organism, Babesia felis, was first described in the Sudan from a wild-caught African wild cat Felis sylvestris (syn: Felis ocreata) $)^{11}$. Although the famous Kenyan lioness 'Elsa' was said to have died of piroplasmosis ${ }^{1}$, feline babesiosis in domestic cats has only been reported from South Africa. It is regarded as endemic in the entire eastern and southern coastal strip from KwaZuluNatal to the Western Cape ${ }^{9}$, but published data on its geographical distribution are scant. There are definite records from Cape Town ${ }^{2,7}$, Bellville $^{4}$, Stellenbosch ${ }^{5}$ and Knysna $^{10}$, all in the Western Cape, and an oblique reference to Port Elizabeth in the Eastern Cape ${ }^{10}$. A small piroplasm isolated from a sick caracal (Felis caracal) in Durban, KwaZulu-Natal, was shown by DNA sequencing to be closely similar to a B. felis isolate from a domestic cat (P A Conrad, University of California-Davis, pers. comm., 1998).

Although B. felis is assumed to be tick-transmitted, the vector has not been identified. References to the yellow dog tick Haemaphysalis leachi being the vector are based on incorrect interpretation of an assumption $^{7,8}$.

Clinical cases presented at veterinary practices in inland provinces, e.g. Gauteng, are usually cats that accompanied their owners on holiday to the coast. A few cases have been reported in cats that had no history of travel. That raises the question whether all small piroplasms in felids are, in fact, B. felis. A small piroplasm, morphologically similar to but serologically distinct from B. felis, isolated from lions (Panthera leo) in the Kruger National Park (KNP) may represent a new species $^{6}$.

Recently, a number of domestic cats with clinical symptoms resembling those of feline babesiosis were presented at a private practice in Nelspruit, Mpumalanga. Small piroplasms were seen on blood smears made from these cats. The cases had originated at Kaapschehoop $\left(25^{\circ} 35.40^{\prime} \mathrm{S}, 30^{\circ} 46.18^{\prime} \mathrm{E}\right)$, a village on the escarpment west of Nelspruit. The cats had not left the environs of the village.

We visited Kaapschehoop and collected serum from 18 cats, to determine the prevalence of infection and the Babesia species involved. Antigen slides of the $B$. felis isolate that had been used in various drug trials ${ }^{9}$ (Lewis B D, Penzhorn B L, Lopez-Rebollar L M, Swan G E, unpubl. data, 1998) were prepared at the Protozoology Section of the Onderstepoort Veterinary Institute. Indirect fluorescent antibody tests were carried out on the sera, by standard procedures. The results are given in Table 1.

We conclude that the piroplasms present in domestic cats at Kaapschehoop are $B$. felis as there is no cross-reaction between that and the KNP lion isolate ${ }^{6}$. Practitioners in towns along the escarpment should be aware of the possibility of clinical cases. With a study site closer to Onderstepoort, we propose further investigations to identify the vector involved.

\section{REFERENCES}

1. Barnett S F, Brocklesby D W 1968 Some piroplasms of wild animals. Symposia of the

Table 1: Results of indirect fluorescent antibody tests against Babesia felis on serum specimens from 18 cats at Kaapschehoop, Mpumalanga.

\begin{tabular}{ccccccc}
\hline & Negative & \multicolumn{5}{c}{ Positive (titre) } \\
\cline { 2 - 7 } & & $1: 80$ & $1: 320$ & $1: 640$ & $1: 1280$ & $>1: 1280$ \\
\hline Number & 7 & 3 & 2 & 1 & 2 & 3 \\
\hline
\end{tabular}

Zoological Society of London 24: 159-176

2. Brownlie J F 1954 Aureomycin in the treatthe South African Veterinary Medical Association 25: 65

3. Davis L J 1929 On a piroplasm from a Sudanese wild cat (Felis ocreata). Transactions of the Royal Society of Tropical Medicine and Hygiene 22: $523-534$

4. Dorrington JE, Du Buy W JC 1966 Ceporan: efficacy against Babesia felis. Journal of the South African Veterinary Medical Association 37: 93

5. Jackson C, Dunning F J 1937 Biliary fever (Nuttalliosis) of the cat: a case in the Stellenbosch District. Journal of the South African Veterinary Medical Association 8: 83-88

6. Lopez-Rebollar L M, Penzhorn B L, De Waal D T, Lewis B D 1999 A possible new piroplasm in lions from the Republic of South Africa. Journal of Wildlife Diseases 35: 82-85

7. McNeil J 1937 Piroplasmosis of the domestic cat. Journal of the South African Veterinary Medical Association 8: 88-90

8. Neitz W O 1956 Classification, transmission, and biology of piroplasms of domestic animals. Annals of the New York Academy of Science 64: 56-111

9. Potgieter F T 1981 Chemotherapy of Babesia nal of the South African Veterinary Association 52: 289-293

10. Robinson E M 1963 Biliary fever (Nuttaliosis) in the cat. Journal of the South African

11. Wilson D E, Reeder D M 1993 Mammal species of the world - a taxonomic and geographic reference (2nd edn). Smithsonian Institution, Washington DC ment of piroplasmosis in the cat. Journal of felis infection: efficacy of certain drugs. JourVeterinary Medical Association 34: 45-47

\section{B L Penzhorn ${ }^{a}$, E Stylianides ${ }^{a}$, M A Coetzee $^{b}$, J M Viljoen $^{b}$ and B D Lewis ${ }^{a, c}$ \\ ${ }^{a}$ Department of Veterinary Tropical Diseases, Faculty of Veterinary Science, University of Pretoria, \\ Private Bag X04, Onderstepoort, 0110 South Africa. \\ ${ }^{b}$ West Acres Veterinary Clinic, Nelspruit, Mpumalanga, South Africa. \\ ${ }^{\circ}$ Department of Biology, Medical University of Southern Africa, Medunsa, 0204 South Africa.}

